UDC 621. $318: 621.397 .6$

\title{
微粒子針状 $\mathrm{Fe}_{3} \mathrm{O}_{4}$ によるビデオテープ の電磁変換特性
}

\author{
東京電気化学工業株式会社 杤原重 三 \\ 並河守
}

小形 VTR 用テープの高記録密度化を目的として，微粒子針状 $\mathrm{Fe}_{3} \mathrm{O}_{4}$ によるビデオテープの試 作実験を行なった。 その電磁変換特性を測定した結果, 現在沉用されている小形 VTR の記録条件 に適合し, 従来用いられている $\gamma-\mathrm{Fe}_{3} \mathrm{O}_{4}$ テープの特性にくらべ感度, 周波数特性, $\mathrm{SN}$ 比などにお いてかなりの改善が認めら机た。

\section{1. ま え がき}

磁気記録テープの高密度記録化を指向し，近年各方面 で磁性材料を中心とした多くの研究が進められている が,なかでむ DuPont 社により開発された $\mathrm{CrO}_{2}$ は従 来の針状 $\gamma-\mathrm{Fe}_{2} \mathrm{O}_{3}$ テープに比較して, より高密度記録に 適しているとされている. しかし, その高保磁力 (テープ 状態で約 450 Oe）のために現在普及しているVTR その 他の記録再生装置では最適記録電流で使用し難いとと, 製造コストが高いとと，さらにキュリ一温度が $135^{\circ} \mathrm{C}$ 付 近にあるため磁性の温度依存性が大きいなどの諸点が問 題とされている。したがって，なるべくこ机らの問題点 が少なく，かつ高性能であることが望ましい，

著者らはその可能性を追求する一端として，微粒子針 状 $\mathrm{Fe}_{3} \mathrm{O}_{4}$ の高保磁力 (粉末状態でつめ量 $0.6 \mathrm{~g} / \mathrm{cm}^{3}$ の とき約 $430 \mathrm{Oe})$ と，フェライト中でも格段に大きい導 電率 $\left(\sigma=2.5 \times 10^{2} \mathrm{mho} \cdot \mathrm{cm}^{-1}\right.$ 常温), また磁性の温度依 存性が小さいなどの諸点に着目して，そのへリカル走查 形 VTR 用テープヘの応用を試みた。 その結果, 現用 VTR の記録条件にただちに適用でき，功，その電磁 変換特性も前記 $\mathrm{CrO}_{2}$ テープにかなり接近したビデオテ 一プを試作することができたので，以下にその概略を報 告する

\section{2. 本実験の目的}

VTR の小形化，カラー化に対処しビデオテープの高

\footnotetext{
"The Magnetic Recording Properties of Video Tape using Very Fine Acicular $\mathrm{Fe}_{3} \mathrm{O}_{4}$ " by Shigezo Tochihara and Mamoru Nami. kawa (TDK Electronics Company Ltd., Tokyo)
}

密度記録特性の向上をはかるため，微粒子釗状 $\mathrm{Fe}_{3} \mathrm{O}_{4}$ を 記録用磁性材料としたヘリカル走查形 VTR 用テープを 試作し，その電磁変換特性を検討する.

\section{3. 磁性粉選択の理由}

高密度記録磁性材料偠要求される諸性質に関しては, すでに諸報告 ${ }^{122}$ にも詳細汇述べられているが，こてで はとくにヘリカル走查形 VTR に適用するととを考慮 し，以下にそれらを要約，列挙する。

(1) 残留磁束密度ができるだけ大きい.

（2）現用 VTR の記録条件に適合させるため，保磁 カはテープ状にしたとき $400 \mathrm{Oe}$ 付近が望ましい.

（3）磁場配向を容易にしテープの角形比 $B_{r} / B_{m}$ を なるべく 1 亿近づけるため, 磁性粉の形状は軸比の 大きい針状であること.

（4）磁性の温度依存性が少ない.

（5）磁性の圧力による変化が少ない.

（6）粒度分布，分散性，吸油率， $\mathrm{pH}$ など顔料的性 質が良好である。

（7）磁気へッドの摩耗を防ぐため, 磁性粉の硬度が 低い.

（8）温度, 湿度などの外的条件に対して化学的に安 定である。

（9）製造コストが高価とならない.

一方，てれらの諸条件を満足しうる可能性があり，か つ現在ただちにビデオテープ用磁性粉として実用的に試 験できる程度に開発されている段階にあるあのを考える と，つぎの 4 種に大別される.

すなわち湿式法による $\alpha-\mathrm{FeOOH}$ を出発原料とした 
微煜子針状 $\gamma-\mathrm{Fe}_{2} \mathrm{O}_{3}$ * (または $\left.\mathrm{Fe}_{3} \mathrm{O}_{4}\right), \mathrm{Co}^{2+}$ 含有 $\gamma-\mathrm{Fe}_{2} \mathrm{O}_{3}$ (粒状, 針状), $\mathrm{CrO}_{2}, \mathrm{Fe} \cdot \mathrm{Co} \cdot \mathrm{Ni}$ 系の合金微粉末などが その主なむのである。しかし，乙れら磁性粉の性質をて

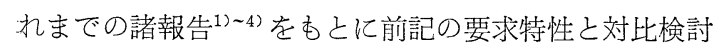
すると, $\mathrm{Co}^{2+}$ 含有酸化鉄は条件 (4), (5) 飞より, $\mathrm{CrO}_{2}$ 粉末は (4), (7), (9), 合金粉末は (6) などにより制約を 受け, 微粒子針状酸化鉄が全般的に特性が均衡を保った 材料として残る.

このうち微粒子 $\gamma-\mathrm{Fe}_{2} \mathrm{O}_{3}$ はすでに高密度ビデオテー プとして適用可能であることが認められ, 明石, 稲津ら により詳細に報告されている3 ${ }^{3)}$ ままた，現在すでにそれ によるビデオテープが製造されており， $H_{c}$ の值は従来 の約 240 Oe から最近は 280 Oe のあのが多くなり, そ れに伴い高域における映像感度が若干改善されている。 しかし, 要求条件 (2) にあ記したとおり，H，はさらに 高く $400 \mathrm{Oe}$ 付近であるととが望ましい.

著者引は，さきに $\alpha-\mathrm{FeOOH}$ の粒度, 粒度分布, 軸 比などを厳密に制御するととにより $H_{c}$ が 380〜 400 Oe の高保磁力 $\gamma-\mathrm{Fe}_{2} \mathrm{O}_{3}$ を製造し, それが高密度録音テー プ用材料として好適であるととを報告した ${ }^{5)}$. あちろん この $\gamma-\mathrm{Fe}_{2} \mathrm{O}_{3}$ のままであビデオテープに適用可能であ るが，さらに $\mathrm{Fe}_{3} \mathrm{O}_{4}$ とするととにより次の諸利点が考 えられる。すすなわち, 周知のように $\gamma-\mathrm{Fe}_{2} \mathrm{O}_{3}$ は $\mathrm{Fe}_{3} \mathrm{O}_{4}$ の低温緩酸化によって得られるが，乙のとき $\mathrm{Fe}_{3} \mathrm{O}_{4}$ の残 留磁化 $B_{r}$ 抢よび $H_{c}$ の值之もに通常 10２0\% 低下す る.したがって, 同一の結晶形態, 粒度分布, 組成の場 合には $\mathrm{Fe}_{3} \mathrm{O}_{4}$ を用いたテープの $B_{r}, H_{c}$ は $\gamma-\mathrm{Fe}_{2} \mathrm{O}_{3}$ の 場合よりつね渂高い.

また最初に記したように， $\mathrm{Fe}_{3} \mathrm{O}_{4}$ はフェライト中とく 纪導電性が大きいため, $\mathrm{Fe}_{3} \mathrm{O}_{4}$ をテープ化するさいに帯 電防止剤の添加を必要としない $\left(\gamma-\mathrm{Fe}_{2} \mathrm{O}_{3}\right.$ テープでは磁 性粉の 15 20 wt\% のカーボンブラックを配合するの が一般的である)。したがって，それだけ塗膜中の磁性 粉含有率が大となり，テープの $B_{r}$ 増大に寄与するとと ができる.

さらに前記の適用条件 (4) すなわち $H_{c}$ の温度依存性 佂関しては, $\mathrm{CrO}_{2}$ 亿比較して $\mathrm{Fe}_{3} \mathrm{O}_{4}$ は $\gamma-\mathrm{Fe}_{2} \mathrm{O}_{3}$ 之同 じく，はるか江安定である。図1亿その実測結果を示し た。同図で試料採取の都合上 $\mathrm{CrO}_{2}$ はテープ状のまま測 定し, 本実験で用いた微粒子針状 $\mathrm{Fe}_{3} \mathrm{O}_{4}$ (以下 $\mathrm{SDB}$ と 記す）は粉体を内径 $4 \mathrm{~mm}$, 長さ $6 \mathrm{~cm}$ のガラス管に均 一につめた状態で測定した。また同図試料 SD $\gamma$ はDB を再酸化して $\gamma-\mathrm{Fe}_{2} \mathrm{O}_{3}$ としたものである.

一方 $\mathrm{Fe}_{3} \mathrm{O}_{4}$ を用いた場合に予想される問題点として,

* 従来の長径約 $1 \mu \mathrm{m}$ をさらに微細化して $0.3 \sim 0.5 \mu \mathrm{m}$ とした針状 $\gamma-\mathrm{Fe}_{2} \mathrm{O}_{3}$

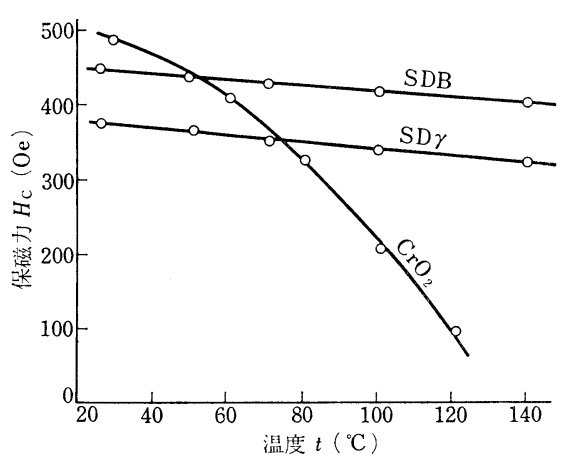

図 1 保磁力の温度依存性

音声トラックの低周波領域に怙ける転写が大であると と, および $\mathrm{Fe}_{3} \mathrm{O}_{4}$ は化学的に準安定な状態にあるため, 長期間保存されたときの磁気的, 化学的な安定性に問題 があるのではないかと考えられる。転写に関しては，初 期の磁気テープに扔いて $\mathrm{Fe}_{2} \mathrm{O}_{3}$ が用いられ, それがやが て $\gamma-\mathrm{Fe}_{2} \mathrm{O}_{3}$ に代った大きな理由のひとつである し，ビデオテープの場合では音質よりも画質に重点がお かれ，あし現行の規格值（たとえば BSS 規格に扔いて は - $54 \mathrm{~dB}$ ) を充分に満足できなくても, 実用上とくに 支障がなければ使用可能であるかす知れない，また磁気 的, 化学的な安定性に関しては今岡(6)により詳細な研究 が行なわれているが，それによれば化学量論的に完全な $\mathrm{Fe}_{3} \mathrm{O}_{4}$ の組成に近け机ば, 化学的にあ磁気的にあ充分安 定であるとされている。

以上の諸理由により, 微粒子針状 $\mathrm{Fe}_{3} \mathrm{O}_{4}$ (試料名 $\mathrm{SDB}$ ) は高密度記録ビデオテープ用磁性粉として使用できる可 能性があり，充分検討する佂值があると考えられる．

\section{4. 実験}

\section{1 試料テープの製造}

Welo-Baudish 法として知られている湿式法により $\alpha-$ $\mathrm{FeOOH}$ を生成するさい飞 $\mathrm{pH}$, 温度, 反応時間を適切 に調節するととにより, 長径約 $0.5 \mu \mathrm{m}$, 軸比 $7 / 1 \sim 9 / 1$ の微粒子 Goethite を製造した。つぎにての微粉末を充 分に水洗したのち $\mathrm{H}_{2}$ 中で加熱還元し $\mathrm{Fe}_{3} \mathrm{O}_{4}$ とした. 得 られた微粒子 $\mathrm{Fe}_{3} \mathrm{O}_{4}$ の諸特性を表 1 亿示す.

上記の磁性粉のテープ化にさいしては, 磁性粉個有の 特性を正確に評価しうると同時に，ビデオテープとして 必要な他の物性（たとえば接着性, 走行安定性, 而摩耗 性, 機械的強度など）も充分満足させることを前提とし て製造試作を行なった。 とくに磁性粉の分散性, 磁気配 向度, 塗膜の表面平滑性などは感度, $\mathrm{SN}$ 比に大きな影 響を与えるので，それらの性質を損なわないように，で きるかぎり実際のビデオテープ製造条件に近い方法で武 料を調整した。 
表 1 試料磁性粉の諸性質

\begin{tabular}{|c|c|}
\hline 項 & 特 性 值 \\
\hline 色調 & 黑 \\
\hline 長軸径 $(\mu \mathrm{m})$ & $0.4 \sim 0.6$ \\
\hline 軸比 & $7 / 1 \sim 9 / 1$ \\
\hline$H_{c} \quad(\mathrm{Oe})$ & $450 \pm 5$ \\
\hline$B r / \rho \quad\left(\right.$ gauss $\left.\cdot \mathrm{cm}^{3} / \mathrm{g}\right)$ & $660 \pm 10$ \\
\hline$B_{m} / \rho \quad$ (gauss $\left.\cdot \mathrm{cm}^{3} / \mathrm{g}\right)$ & $1200 \pm 10$ \\
\hline$B r / B_{m}$ & 約 0.55 \\
\hline $\mathrm{pH}$ & $7.5 \pm 0.5$ \\
\hline $\mathrm{SO}_{4}{ }^{2-}$ 含有率 $(\%)$ & 0.55 以下 \\
\hline みかけ密度 $\left(\mathrm{g} / \mathrm{cm}^{3}\right)$ & $0.25 \pm 0.05$ \\
\hline
\end{tabular}

すなわち, 磁性塗膜に要求される上述の物性を得るた めに, 耐熱性, 耐摩耗性, 接着性にすぐれた熱硬化性ポ リウレタン樹脂と磁性粉とを重量比で $1 / 3.5$, すなわち CPVC (critical pigment volume concentration) とな るように配合し，MEK，THF，トルオールなどの各種 溶剂，稀釈剂，および油脂系の分散剂を適量加えて予備 混合を行なった。つぎそれをボールミルに投入し，さ らに溶剂を加え適切な粘度に調節した後, 約 $50 \mathrm{hr}$ 回転 を続け，充分に磁性粉が分散した磁性塗料とした，精密 フィルターにより異物, 未分散磁性粉などを完全に除去 したのち，ドクターブレード方式による塗布機を用い， 塗布速度約 $10 \mathrm{~m} / \mathrm{min}$, 乾燥温度 $40 \sim 120^{\circ} \mathrm{C}$ で $25 \mu \mathrm{m}$ 厚 さのポリエチレンテレフタレートベース上に均一に塗布 した。 なお，塗布直後 1500 Oe の直流磁場により，テ 一プの長さ方向に磁場配向処理を施こした．また乾燥工 程直後に線圧 $30 \mathrm{~kg} / \mathrm{cm}$, 温度 $25 \pm 2^{\circ} \mathrm{C}$ でカレンダーロ 一ルによる表面処理を行なった。ささらに熱硬化させるた めに塗布ずみの試料を $80^{\circ} \mathrm{C}$ に $24 \mathrm{hr}$ 保持し硬化反応終 了後に $12.7 \pm 0.01 \mathrm{~mm}$ の幅に切断して試料とした.

\section{2 電磁変換特性の測定条件}

電磁変換測定機として，日本ビクタ一製 KV 800 形 VTR を用いた，同装置の主な諸元は 2 ヘッド・スラン トトラック方式，テープ走行速度 $24.0 \mathrm{~cm} / \mathrm{sec，ヘッド・}$ テープ間相対速度 $13.7 \mathrm{~m} / \mathrm{sec}$, 映像信号の入出力特性, および周波数特性は映像信号プリアンプ入力側に高周波 発振器, ヘッド再生出力アンプ出力側に電圧計を接続 し，周波数範囲 1 $5 \mathrm{MHz}$ で測定した。 また $\mathrm{SN}$ 比の測 定は同回路に执いて，映像信号入力側に階段波信号（グ レイスケール）を加えて記録再生し，その出力とその上 に重畺された雑音成分の比を求めた.

音声トラックの電磁変換特性は，映像信号の電磁変換 特性測定終了後の試料を $6.25 \mathrm{~mm}$ 幅に切断し, 一般の 録音用テープと同じく BSS (P 5303) の標準に従って測 定した。なお，比較試料とした $\mathrm{CrO}_{2}$ テープは $\mathrm{Du}$ Pont 製， $\gamma-\mathrm{Fe}_{2} \mathrm{O}_{3}$ テープは $3 \mathrm{M}$ 製であり，いずれあ最近の 市販品より任意に選択したものである。



図 2 記録電流特性 $(I)$

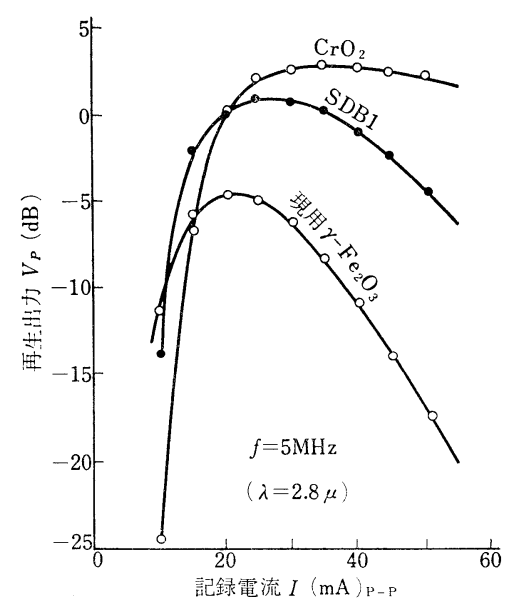

図 3 記録電流特性 $($ II)

\section{3 測定結果および考察}

図 2, 図 3 に記録周波数を $3 \mathrm{MHz}$ および $5 \mathrm{MHz}$ に したときの入出力特性を示す. 図 4 は記録電流を $30 \mathrm{~mA}$ 一定（現用 $\gamma-\mathrm{Fe}_{2} \mathrm{O}_{3}$ テープの最適記録電流，周波数 3 $\mathrm{MHz})$ としたときの映像信号領域における周波数特性で

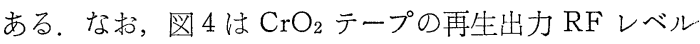
を $0 \mathrm{~dB}$ としたときの相対出力值で表わしてある.

これらの図から明らかなように, 試料テープ SDB 1 は 現用 $\gamma-\mathrm{Fe}_{2} \mathrm{O}_{3}$ デープに比較して, 再生出力は $3 \mathrm{MHz}$ で は約 $3 \mathrm{~dB}, 5 \mathrm{MHz}$ では約 $5 \mathrm{~dB}$ の増大が認められる. また $\mathrm{CrO}_{2}$ と比較してあ記録電流が $30 \mathrm{~mA}$ 付近（すな わち現在汎用されているへリカル走查形 VTR との互換 性を前提とした場合）では，かなり接近した值を示し， $5 \mathrm{MHz}$ 程度の短波長領域においても，その差はわずか $2 \mathrm{~dB}$ 程度となり，実用上は同等に近い。しかし，記録 電流をさらに増大させた場合は $\mathrm{CrO}_{2}$ テープの特質が発 揮され，とくに高域においては $\mathrm{CrO}_{2}$ テープと $\mathrm{SDB}$ テ 


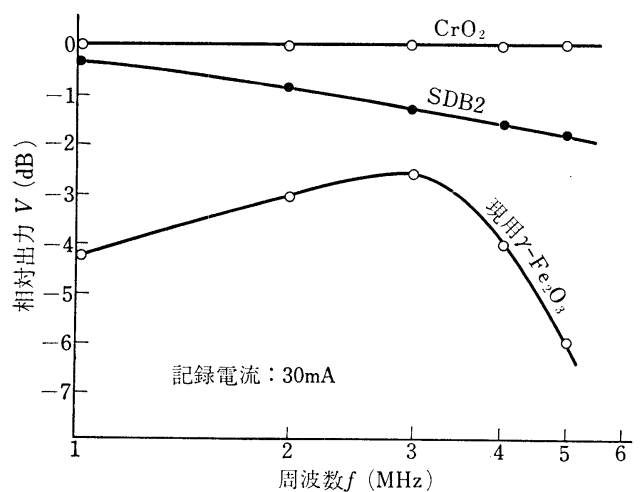

図 4 RF 再生出力特性

表 2 試作テープの主な特性

\begin{tabular}{l|r|r|r}
\hline \hline \multicolumn{1}{c|}{ 項 } & 目 & SDB1 & $\mathrm{CrO}_{2}$ テープ \\
\hline 全 厚 $(\mu \mathrm{m})$ & 30.2 & 30.0 & 27.5 \\
磁性膜厚 $(\mu \mathrm{m})$ & 6.2 & 6.0 & 4.3 \\
$B_{r}$ (gauss) & 1057 & 1020 & 1690 \\
$B_{r} / B_{s}$ & 0.75 & 0.75 & 0.91 \\
$H_{c}(\mathrm{Oe})$ & 380 & 378 & 450 \\
映像感度*1 $(\mathrm{dB})$ & -0.9 & -1.6 & 0 \\
" SN 比*2 $(\mathrm{dB})$ & -0.4 & -1.0 & 0 \\
音声感度*3 $(\mathrm{dB})$ & -2.0 & -2.0 & 0 \\
" 転写 $(\mathrm{dB})$ & -47.0 & -47.0 & -54.2 \\
電気抵抗*4 $(\Omega)$ & $1.0 \times 10^{9}$ & $1.0 \times 10^{9}$ & $3.5 \times 10^{8}$ \\
表面光沢度*5 & 2.6 & 2.0 & 4.0 \\
\hline
\end{tabular}

*1 記録電流 $30 \mathrm{~mA}, 3 \mathrm{MHz}, \mathrm{CrO}_{2}$ との相対値

*2 変調度 $50 \%$, 記録電流 $30 \mathrm{~mA}, \mathrm{CrO}_{2}$ との相対值

*3 バイアス電流 $380 \mathrm{~mA}, 1 \mathrm{kHz}, \mathrm{CrO}_{2}$ との相対值

*4 試料片 $12.7 \times 35 \mathrm{~mm}^{2}$, 長さ方向測定, $n=5$

*5 表面反射率計による，標準ガラス表面の反射率を 1 をとしたときの相 対値

ープとの差は 3〜 4 dB となる.

表 2 は上記以外の特性項目，たとえば磁気特性，SN 比，録音特性などをまとめて表にしたあのである，録音 特性におけるバイアス特性，入出力特性（ひずみ率を含 む) はそれぞれ図5, 図6に示した。表 2 において, SDB 2 は, SDB 1 の再現性を確認する意味で SDB 1 と すべて同一条件でくり返し実験を行なったあのであり， 結果に打いても双方間に特別に大きな差異は認められな w.

同表の諸項目のうち特に考慮すべき問題として，はじ めに予想されたように転写が現在の録音テープの水準, -52〜 - $54 \mathrm{~dB}$ の值より若干劣化し $-47 \mathrm{~dB}$ の值となっ たととがあげられる。この要因としては $\mathrm{Fe}_{3} \mathrm{O}_{4}$ の微粒子 性に起因する熱ゆらぎの問題, $\mathrm{Fe}_{3} \mathrm{O}_{4}$ の初期磁化曲線の 形状，ボールミルなどの機械的粉砕に伴う粒子分布の広 がり, ベース厚など，多くの因子が複雑にからみあって いるあのと推定される。詳細な解析はさらに広範囲な実 験ならびに厳密な検討を加えたのち改めて報告したい.

また, テープの電気抵抗においても, $\mathrm{SDB}$ と $\mathrm{CrO}_{2}$ との間に約 1 桁の差異が認められる。乙れは $\mathrm{CrO}_{2}$ の導



図 5 バイアス曲線

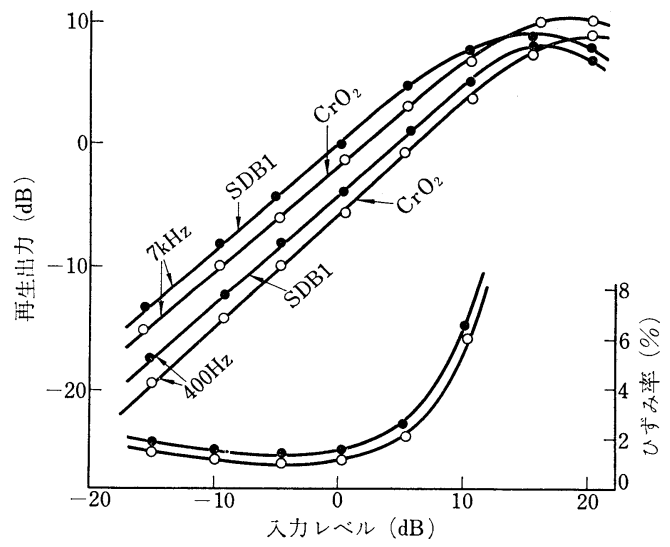

図 6 入出力, ひずみ特性

電性が， $\mathrm{Fe}_{3} \mathrm{O}_{4}$ よりもさらに良好（焼結状態，常温での 抵抗率が $1 \times 10^{-4} \Omega \cdot \mathrm{cm}$ 程度）であるためと解せられる. しかしテープの電気抵抗は本測定法 ${ }^{12)}$ で, $1 \times 10^{9} \Omega$ 程度 以下であれば, 帯電障害はほとんど発生しないととが知 られているので8), SDB テープでは実用上問題がないと してよい.

また著者が $\mathrm{Fe}_{3} \mathrm{O}_{4}$ のテープの電気抵抗に寄与する効果 を確認するため, $\mathrm{Fe}_{3} \mathrm{O}_{4}$ の代りに $\gamma-\mathrm{Fe}_{2} \mathrm{O}_{3}(\mathrm{SDB}$ と同一 ロットの $\alpha-\mathrm{FeOOH}$ から得たもの) を用い, 他の条件 を全く同じにしてテープ化した予備実験では，テープの 電気抵抗は $1 \times 10^{11} \Omega$ 以上の值を得ている，さらにこの 值を SDB テープと同じ值に近づけるためには，帯電防 止用カーボンブラックを $\gamma-\mathrm{Fe}_{2} \mathrm{O}_{3}$ に対して約 $20 \mathrm{wt} \%$ 添加する必要があり，それに応じて塗膜中の磁性粉含有 率は $\mathrm{Fe}_{3} \mathrm{O}_{4}$ (または $\gamma-\mathrm{Fe}_{2} \mathrm{O}_{3}$ ） のみのときの值，1.5〜 $1.6 \mathrm{~g} / \mathrm{cm}^{3}$ から $1.4 \sim 1.5 \mathrm{~g} / \mathrm{cm}^{3}$ に低下し, 当然テープ の $B_{r}$ むそれに比例して減少することが同予備実験から 認められた。

また，本実験の主題である高密度記録特性に関して， 実測値と Speliotis の実験式をむとにした推定值の対比 を試み表 3 に示した，従来，短波長記録再生機構の理論 
的解析について多くの研究報告が発表9)されているが, まだ実際の記録再生特性と記録媒体諸定数とを定量的に 結びつけ，高密度記録テープ製造条件に直接適用できる 理論式を得るまでに至っていないようである。したがっ て，現実には経験による試行錯誤的な方法，あるいは現 象論的な実験式にもとづいて媒体諸定数を決定する場合 が多い，乙れらの実験式のうち，ディジタル記録再生に おける Speliotis ${ }^{10)}$ の式をあげると次のとおりである。

$$
\begin{aligned}
& E_{p} \propto\left(B_{r} \cdot \delta \cdot H_{c}\right)^{0.5} \\
& W_{50} \propto\left(B_{r} \cdot \delta / H_{c}\right)^{0.5}
\end{aligned}
$$

こてで $E_{p}$ はパルス再生出力波形の波高値, $W_{50}$ は波 形半値幅, $\delta$ は磁性膜厚である。

VTR における映像信号は，FM 変調された複合周波 信号として直接記録方式により高密度記録されるので, テープ上の残留磁化は非直線的となり，ディジタル記録 の高密度記録状態にある程度近づくと考えられる，そこ で上の (1) 式が本実験の場合にも近似的に適用できると 仮定し, $\mathrm{CrO}_{2}$ と $\mathrm{SDB}$ の映像感度を相対值として概算 したものが表 3 の計算である，ただしての場合，テー プ・ヘッド間の間隙損は全く考慮していない，

表 3 より, 記録周波数 $3 \mathrm{MHz}$ (波長 $4.6 \mu \mathrm{m}$ ) では計 算式と実験式とは比較的近似した值を得るが，さらに高 域の $5 \mathrm{MHz}$ では双方の差はかなり大きくなる。乙れは 記録波長か短くなるに従って本計算で無視されている $20 \log \exp (2 \pi \delta / \lambda)$ にもとづく間隙損による 差異が顕著 となるととあ大きな原因のひとつと考えられる。

記録再生中に打ける真の間隙を測定するととはきわめ て困難であり，実際にはテープ表面光沢度などにより， テープ・ヘッド間の密着性を推定するととが多い11)，表 2 の光沢度の值においてお， $\mathrm{CrO}_{2}$ 之 $\mathrm{SDB}$ の間にいく らかの差が認められ, この差が短波長に近づくほど $\mathrm{CrO}_{2}$ と SDB の出力差として表われる。逆にいえば，SDBの 表面性を $\mathrm{CrO}_{2}$ と同じ程度に上昇させるとすれば，SDB の高域特性はさらに $\mathrm{CrO}_{2}$ に近づく可能性がある.

また，前述の計算では飽和記録されているとみなし，

\begin{tabular}{|c|c|c|c|c|}
\hline & $\mathrm{CrO}_{2}$ & SDB1 & SDB2 & $\gamma-\mathrm{Fe}_{2} \mathrm{O}_{3}$ \\
\hline$B r$ (gauss) & 1690 & 1075 & 1020 & 875 \\
\hline$H_{c}(\mathrm{Oe})$ & 450 & 380 & 378 & 291 \\
\hline$\delta(\mu \mathrm{m})$ & 4.3 & 6.2 & 6.0 & 6.0 \\
\hline \begin{tabular}{l|l} 
相 & 計 算 值 \\
対
\end{tabular} & 0 & -1.1 & -1.5 & -3.4 \\
\hline 出 実測值 $3 \mathrm{MHz}$ & 0 & -0.9 & -1.6 & -2.8 \\
\hline$\underset{(\mathrm{dB})}{\text { 力 }}$ & 0 & -1.5 & -1.8 & -6.3 \\
\hline 表面光沢度 & 4.0 & 2.6 & 2.0 & -3.0 \\
\hline
\end{tabular}

表 3 映像出力相対值の計算

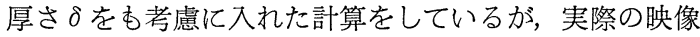
信号の短波長記録の範囲内では，厚さに関係なく磁性膜 表面層のみで記録再生が行なわれると考えられるので， (1)式をそのまま映像信号記録に適用するには若干の問 題があるかるしれない.

さらに，本実験における残された問題として，テープ を長期間保存したときの磁気的，化学的安定性の確認が ある。乙机についてはお多くの時間をかけて検討する 必要がある。

\section{5. むす び}

以上，ヘリカル走查形 VTR 用テープの高密度記録化 を目標にして，微粒子針状 $\mathrm{Fe}_{3} \mathrm{O}_{4}$ によるビデオテープの 試作実験を行なった。その電磁変換特性を測定した結果, 現在汎用されている小形 VTR の記録条件に適合し，従 来用いられている $\gamma-\mathrm{Fe}_{2} \mathrm{O}_{3}$ テープの特性にくらべ，感 度，周波数特性， $\mathrm{SN}$ 比などに扔いてかなりの改善がみ られ，実用上 $\mathrm{CrO}_{2}$ テープの水準に接近しうる可能性を 確認するととができた，また，磁性の温度依存性，なら びに製造コストなどの点では，むしろ $\mathrm{CrO}_{2}$ よりも有利 であると考えられる。

しかし $\mathrm{CrO}_{2}$ テープの最適記録条件下で比較した場合 では $\mathrm{CrO}_{2}$ のほうが短波長領域における感度がはるかに 高い。 また，微粒子 $\mathrm{Fe}_{3} \mathrm{O}_{4}$ の問題点ならびに未確認事項 として, 転写, 長期保存に対する安定性の問題等が残さ れている。

おわりに，本研究発表にあたりご指導をいただいた東 京工業大学 星野愷名誉教授，で協力をいただいた戸田 工業 故戸田英夫社長， 清水恵己氏，また発表の機会を 与えられた東京電気化学工業 素野福次郎社長, 平賀貞 太郎開発研究所長，その他多くの方々飞深謝する。

(昭和 46 年 2 月 22 日受付)

\section{〔参 考 文 献〕}

1) 星野愷: 電気化学, 38 (1970) 536

2）岩崎俊一，大内一弘：テレビ誌， 23 (1969) 26

3）明石五郎，稲津稔ほか：テレビ誌， 21 (1967) 494

4) たとえば星野愷：磁気テープ (新しい工業材料の科学，複合材料 IV, 電子工業材料), p. 27, 金原出版 (1969)

5) 杤原重三，並河守：通信学会磁気記録研資 (1965．5)

6) M. Camras：特許公昭 26-7776

7) 今岡保郎：電気化学, 33 (1965) 226

8）林謙二，横山克哉：NHK 技術研究， 16 (1969) 140

9) たとえば岩崎俊一：信学誌，52 (1969) 1241

10) D. E. Speliotis: IEEE Trans., MAG-4, 3, Sep. (1968) 553

11) 村松珊吾, 山鹿親幸：通信学会磁気記録研資, MR 68-6 (1968)

12）杤原重三: テレビ誌, 20, 5 (1966) 330 